\title{
Discovery and significance of Quaternary aqueously deposited aeolian sandstones in the Sanhu area, Qaidam Basin, China
}

\author{
Wen-Jing Mao ${ }^{1,2} \cdot$ Shao-Bin Guo ${ }^{1,2}$
}

Received: 3 July 2017 / Published online: 20 January 2018

(c) The Author(s) 2018. This article is an open access publication

\begin{abstract}
Influenced by neo-tectonic movement, the Sanhu area of China's Qaidam Basin formed in the Quaternary in response to migration of its depocentre. A study of core material from the Qijia 1 Well reveals novel Quaternary aqueously deposited aeolian sandstones in the Qigequan Formation of the Sanhu area. Here we report the sedimentary petrology and geochemistry data of these deposits that constrain their depositional history. Evidence for aeolian influence during deposition includes: sorting and roundness, pure quartz sand with single mode grain size distribution and few suspension materials, very fine sand grain size distribution indicating sorting by saltation and suspension transport, dish-shaped and crescentshaped pits in grain surfaces indicating aeolian transport and chemical composition similar to that observed in active or recent dune deposits, namely enrichment in $\mathrm{SiO}_{2}, \mathrm{Na}_{2} \mathrm{O}$, and $\mathrm{MgO}$ relative to the sand dam sediment in the lakeshore. Identification of these aqueously deposited aeolian sandstones expands the range of sedimentary deposit types found in the Sanhu area and improves understanding of its paleoclimatic history.
\end{abstract}

Keywords Qaidam Basin · Qigequan Formation · Aqueously deposited · Aeolian sandstones · Paleoclimate

\section{Introduction}

Aeolian sandstones are formed by wind, abrasion and diagenesis in arid environments. The two types of aeolian sandstones, buried and residual deposits, are distinguished according to their state of preservation. In buried deposits, sedimentary cover preserves lenticular sand dune structures. In residual deposits, exposure at the surface and diagenesis erase original sedimentary structures. Over the last few years, various Quaternary aeolian deposits have been discovered throughout China including the Ordos Plateau and Qaidam Basin (Hu et al. 2001).

The Qaidam Basin is influenced by westerly winds and both Asian and south-west monsoon systems. As such, it

Edited by Jie Hao

Shao-Bin Guo

guosb58@126.com

1 School of Energy Resources, China University of Geosciences, Beijing 100083, China

2 Key Laboratory of Marine Reservoir Evolution and Hydrocarbon Enrichment Mechanism, Ministry of Education, Beijing 100083, China records regional responses to variations in the global climate system. Since the Late Cenozoic, neo-tectonic movements have caused the basin's depositional centre to migrate east, forming Quaternary deposits in the Sanhu area. Many scholars have investigated recent sedimentary environments of the Sanhu area to conclude that Quaternary deposition consisted primarily of clastic sediments deposited as lakeshore facies (Xie and Guan 2000; Guo and Chen 2008; Guo et al. 2011).

This study performed detailed analysis of cores from the Qijia 1 Well. Petrographic analysis using stereo microscopy, scanning electron microscopy (SEM) and chemical analysis methods revealed structures, grain size distributions, textural features and chemical compositions indicative of aeolian sandstones. Discovery of aqueously deposited aeolian sandstones expands the range of known sedimentary environments in the Sanhu area and refines understanding of its paleoclimatic history. 


\section{Geological setting}

The Sanhu area, located in the eastern Qaidam Basin, represents a first-order tectonic unit delineated by three saline lakes: Taijinar, Suli, and Dabsan Lakes. The Sanhu area covers over an area of $60,000 \mathrm{~km}^{2}$ and lies between the Chuanxingqiu structure to the west and the Nuomuhong area to the east (Fang et al. 2007).

Neogene tectonic episodes shifted the Qaidam depositional centre from west to east. The basin reached its maximum depth of over $3200 \mathrm{~m}$ in Suli Lake. The basin consists of three secondary tectonic units differentiated according to thickness and deformation. These include the Salt Lake structural belt, the Suli Lake Depression and the Dabsan Lake Depression (Table 1). The Qijia 1 Well samples a south-westerly limb of the Salt Lake structure belt and extends $3950 \mathrm{~m}$ through the Quaternary (Fig. 1). Sedimentary cover consists primarily of Gobi desert deposits including saline and alkali material containing no vegetation. The Qigequan Formation $\left(\mathrm{Q}_{1+2}\right)$ sampled by the Qijia 1 Well is lithologically dominated by sandstonemudstone interbeds that reach a total thickness of $1411 \mathrm{~m}$. These include grey, grey black and off-white mudstones, and sandy mudstones, followed by grey, dark grey and offwhite argillaceous siltstones, minor pale yellow mudstones, grey carbonaceous mudstones, and off-white siltstones, which are lacustrine sediments. The upper part consists of grey to black carbonaceous mudstones (Fig. 2). Sandstones contain plant debris while mudstones contain debris from ostracod species of lyocypris and Qinghaicypris crassa. These fossils only found in the freshwater-less saline sediment, reflecting low temperature conditions, are the division of the Quaternary and the Neogene in Qaidam Basin (Xie and Guan 2000).

\section{Samples and analysis}

Samples analysed included 28 core samples from the Qijia 1 Well of the Sanhu Depression (Qaidam Basin), a sand sample from Mingsha Mountain and an aeolian sand from an area near Qinghai Lake. Each sample was divided into five aliquots for thin section analysis, grain counts, physical property analysis, scanning electron microscopic imaging and compositional analysis.

Thin sections were examined using a Zeiss Axio Scope A1 stereo microscope for the identification of sandstone shapes. Texture and grain morphology were imaged using a TESCAN Vega2 scanning electron microscope (SEM). Samples examined with SEM were washed in $10 \%$ hydrochloric to isolate quartz grains. X-ray fluorescence spectrometry (XRF) was used to determine major element compositions.

\section{Results}

\subsection{Sedimentary characteristics}

Stereo microscopic imaging showed that sandstone core material from $866.6 \mathrm{~m}$ depth (Qijia 1 Well) consisted mostly of sand exhibiting high textural maturity, grain support and pore cementation. Rock types consisted of medium to fine grained lithic quartz sands encapsulated by regular iron clay. Compositions consisted of more than $75 \%$ quartz and debris representing between $15 \%$ and $20 \%$. Clastic textures categorized as well-sorted and rounded pure quartz sand with single mode grain distribution and few suspension materials (Fig. 3a). A core sandstone sample from $876 \mathrm{~m}$ (Qijia 1 Well) exhibited angular to subangular textures and low textural maturity (Fig. 3b). Core sandstones at $866.6 \mathrm{~m}$ (Qijia 1 Well) resembled
Table 1 Stratigraphic system and contact relations for the eastern Qaidam Basin

\begin{tabular}{lllll}
\hline Erathem era & System period & Series epoch & Symbol & Formation \\
\hline Cenozoic & Quaternary & Holocene & $\mathrm{Q}_{4}$ & Yanqiao Formation \\
& & Upper Pleistocene & $\mathrm{Q}_{3}$ & Dabsan Formation \\
& Middle Pleistocene & $\mathrm{Q}_{1+2}$ & Qigequan Formation \\
& Lower Pleistocene & & \\
& Neogene & Pliocene & $\mathrm{N}_{2}^{3}$ & Shizigou Formation \\
& & $\mathrm{N}_{2}^{2}$ & Upper Youshashan Formation \\
& & $\mathrm{N}_{2}^{1}$ & Lower Youshashan Formation \\
& & $\mathrm{N}_{1}$ & Upper Gancaigou Formation \\
& Miocene & $\mathrm{E}_{3}$ & Lower Gancaigou Formation \\
& Oligocene & $\mathrm{E}_{1+2}$ & Lulehe Formation \\
Paleozoic & Eocene & & \\
& Paleocene & $\mathrm{K}-\mathrm{J}$ & \\
& & $\mathrm{Bedrock}$ & \\
& & &
\end{tabular}




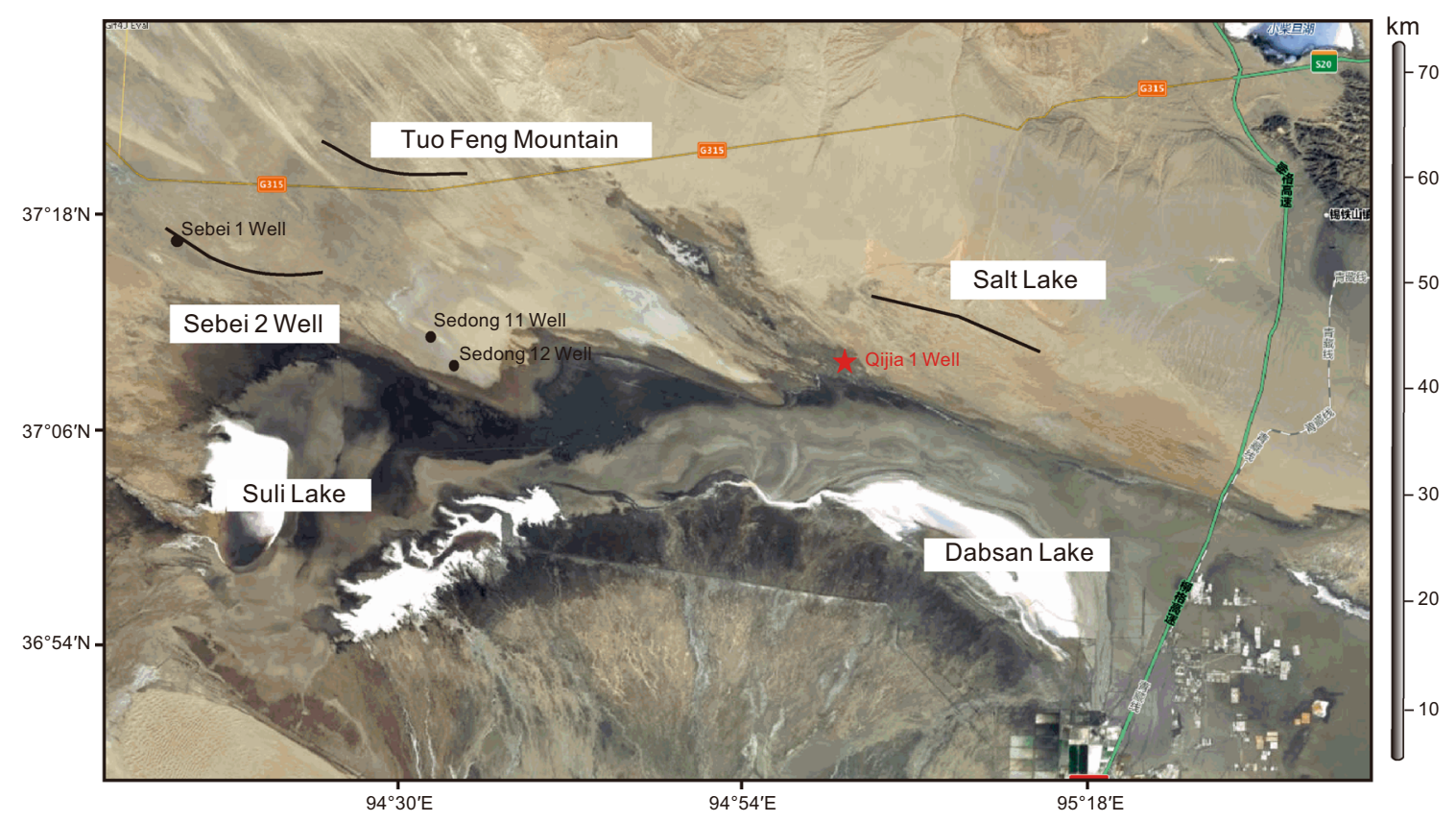

Fig. 1 Geological topographic map of the Sanhu area, Qaidam Basin

aeolian deposits in the Chinese Loess Plateau ( $\mathrm{Lu}$ et al. 2001), south-west France (Bertran et al. 2011), and outcrop around Mingsha Mountain (Fig. 3c). In contrast, core material from $876 \mathrm{~m}$ differs from the aforementioned sandstone examples. Stratigraphic analysis of Qijia 1 Well cores identified 19 aqueously deposited aeolian horizons within the Qigequan Formation. These layers showed a maximum thickness of $10 \mathrm{~m}$, a minimum thickness of $1.4 \mathrm{~m}$ and an average thickness of $4.6 \mathrm{~m}$. Based on the deposition rate (Guo 2008), the depositional age of the aqueously deposited aeolian sandstones (Fig. 3) was determined.

\subsection{Textural characteristics}

\subsubsection{Grain size distributions}

Core sandstones from 382-386, 866.6, and $1138.8 \mathrm{~m}$ gave mean Krumbein phi values of $4-8$ and 3-4 $\Phi$, sorting coefficients between 1 and 2, skewness greater than 0.3 , and a kurtosis exceeding 1.56. Rock types are categorized as coarse siltstone and siltstone. Cumulative curves (Fig. 4a) show sandstone samples forming two lines indicating the influence of saltation and suspension during transport. The abscissas $(\Phi)$ of the truncation points for these two components ranged from 4 to 5 while their ordinates (accumulative content percentage) ranged from $95 \%$ to $99.5 \%$. This indicates that core sandstone samples from 382 to $386,866.6$, and $1138.8 \mathrm{~m}$ consist primarily of saltation components with a minor suspension component.
Transport by a single mode left them well sorted. These sedimentary characteristics overlap with those found in modern aeolian sands from Mingsha Mountain (Fig. 4c) and suffice to discriminate them from lakeshore facies (Goudie 1987; Hu et al. 2001; Mountney and Russell 2004, 2009; Zhang et al. 2011; Bertran et al. 2011, 2016). Aeolian horizons of the Qigequan Formation also contain some clay and mica particles apparently transported by the wind and deposited under lacustrine conditions.

Core sandstone from 876, 1140-1145, and $1803.08 \mathrm{~m}$ gave Krumbein phi values of 3-4 and 2-3 $\Phi$, sorting coefficient ranging from 3 to 4 , a skewness of 0.3 , and a kurtosis ranging from 0.9 to 1.11 . Grain size distributions categorize these samples as coarse siltstone and siltstone (Table 2). Cumulative curves (Fig. 4b) show sandstone samples forming two lines indicative of saltation and suspension transport modes. The abscissas $(\Phi)$ of the truncation points for these two components ranged from 2 to 3 and ordinates (accumulative content percentage, \%) ranged from $95 \%$ to $99 \%$. This indicates that core sandstones from 876, 1140-1145, and $1803.08 \mathrm{~m}$ experienced major suspension transport and only minor saltation. We therefore interpret these core intervals as representing lakeshore facies.

\subsubsection{Morphology and textural characteristics of quartz sands}

As a sedimentary process, wind causes rounding of clastic particles. With the exception of subangular particles hosted 


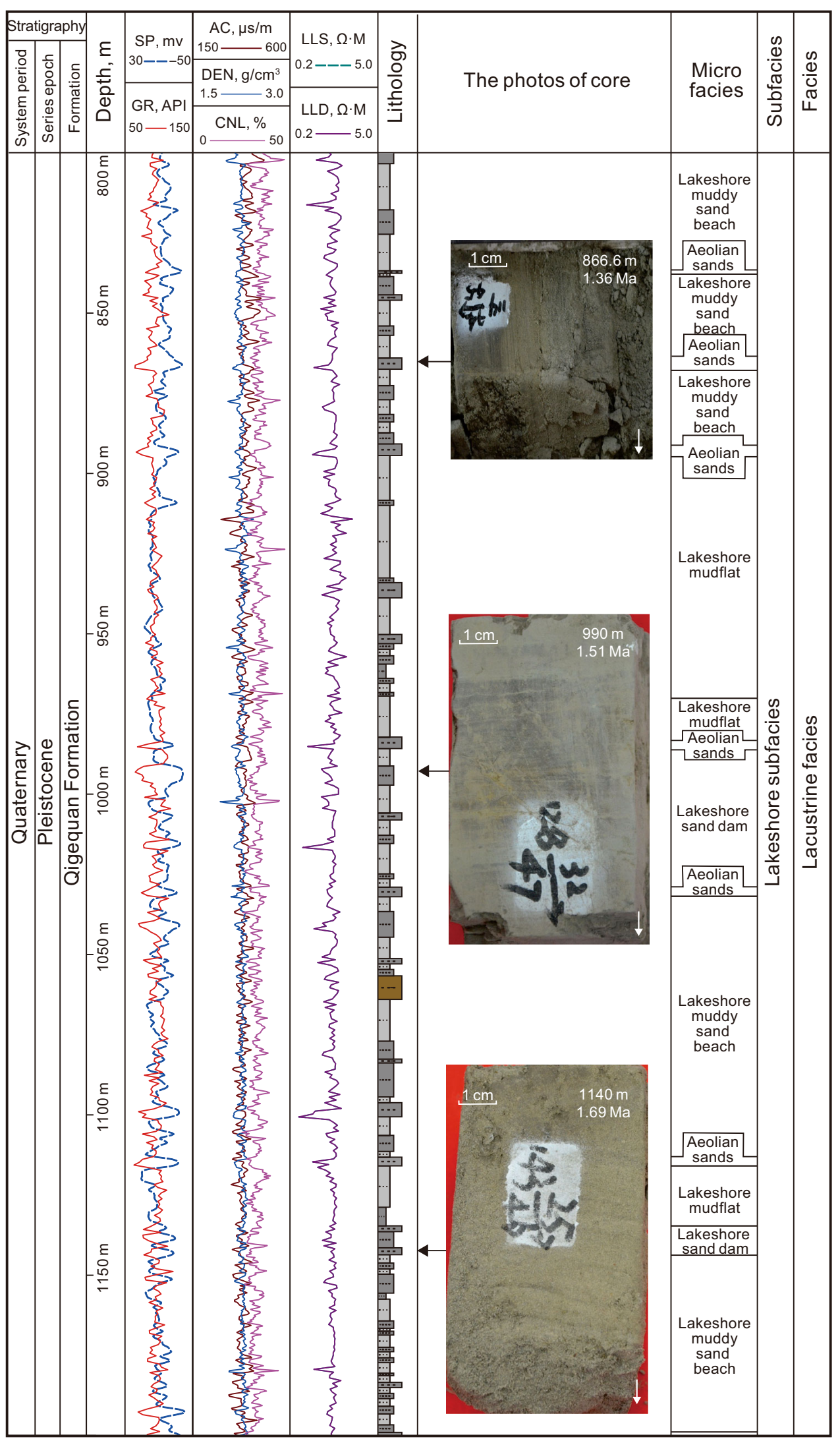

Fig. 2 Sedimentary characteristics and synthesis column map of the Qigequan Formation from the Qijia 1 Well core 

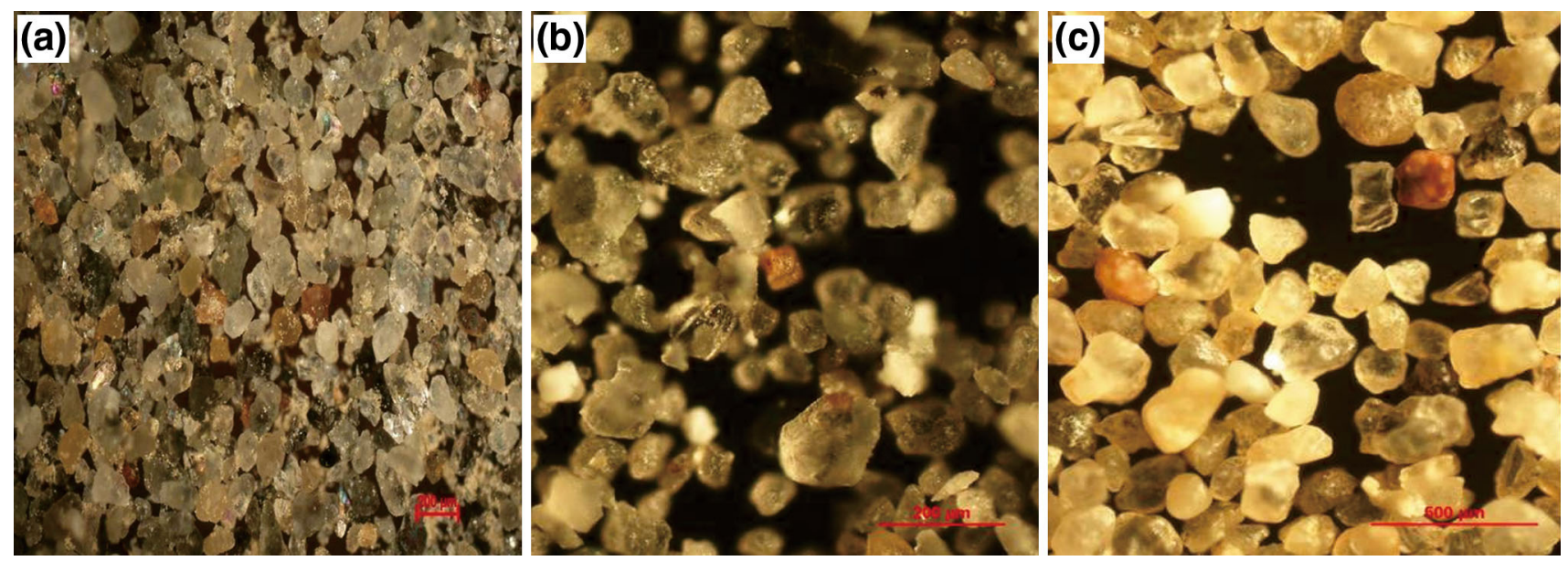

Fig. 3 Petrographic features of sandstones from core material at $866.6 \mathrm{~m}(\mathbf{a}), 876 \mathrm{~m}$ (b) and modern aeolian deposits (c) imaged by stereo microscopy
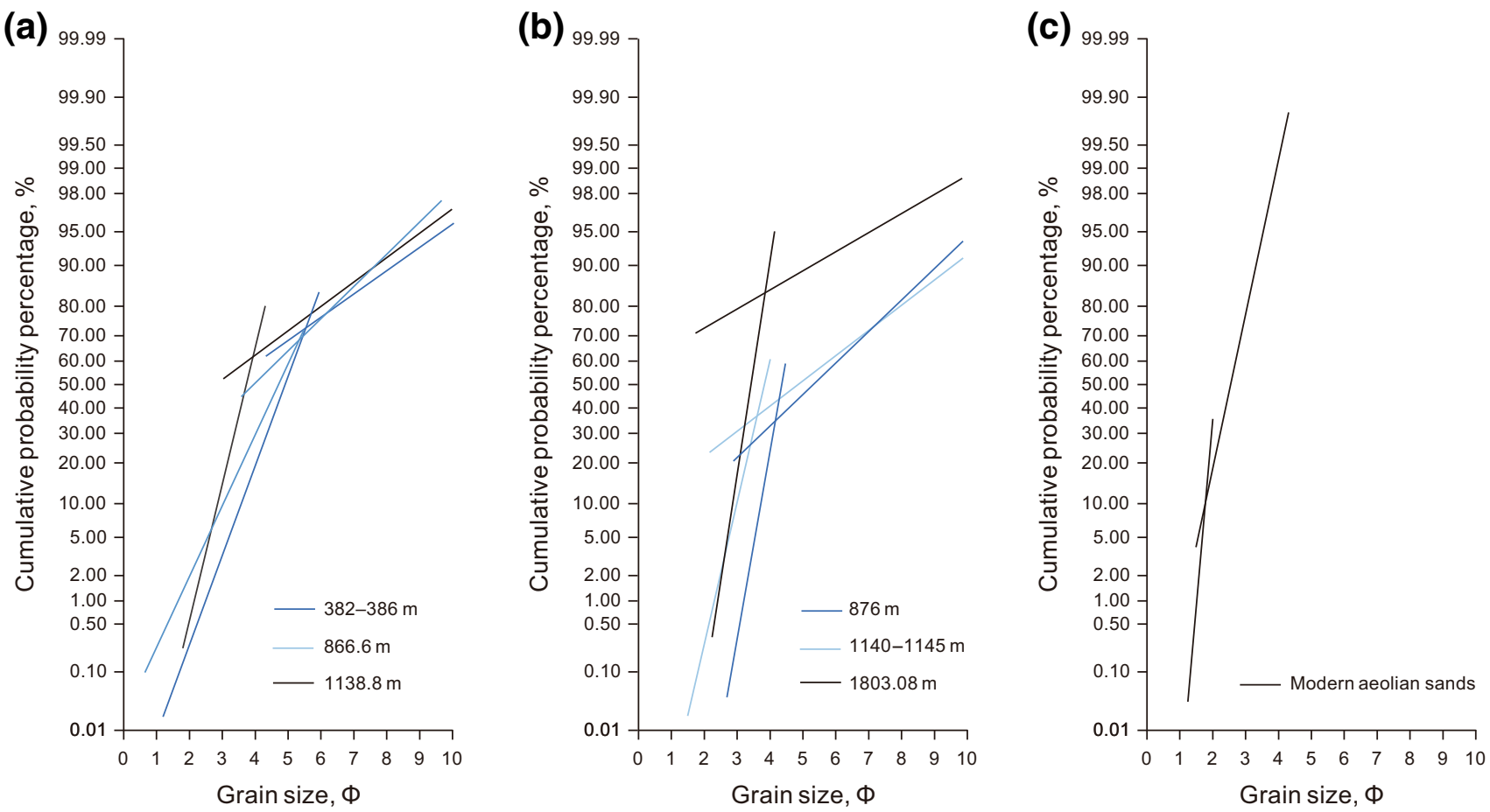

Fig. 4 Cumulative grain size curves for sandstones from the Qigequan Formation and for sediment from modern aeolian deposits. a Core material from 382 to $386,866.6$, and $1138.8 \mathrm{~m}$. b Core material from 876, 1140-1145, and $1803.08 \mathrm{~m}$. c Sediment from modern aeolian deposits

by linear dunes, sediment rounding, and other signs of abrasion serve to differentiate aeolian from lacustrine deposits. The presence of small, irregular pits in the surface of particles $>100 \mu \mathrm{m}$ and frosted grain textures indicates wind abrasion. Dish-shaped and disciform pits with both regular and arcuate edges formed in highly rounded particles indicate high-intensity wind. These pits range $10-30 \mu \mathrm{m}$ in depth in particles $100 \mu \mathrm{m}$ in diameter (Mongelli et al. 2006; Abdullah and Eswaran 2014; Refaat and Hamdan 2015). Conchoidal fracture of quartz grains is interpreted as evidence of glacial deposition (Mahaney et al. 2001; Cowan et al. 2008; Deane 2010).

Core material from the Qigequan Formation was imaged by scanning electron microscope (SEM). Images showed that samples from $866.6 \mathrm{~m}$ (Fig. 5c) and $1138.8 \mathrm{~m}$ (Fig. 5d) consisted of moderately well-rounded particles. Grains appeared subrounded to subangular and exhibited surfaces with dish-shaped pits and crescent-shaped pits. Sandstones collected from areas surrounding Qinghai Lake and Mingsha Mountain show similar characteristics 
Table 2 Mean graphical textural values for sandstones from the Qigequan Formation and for sediment from modern aeolian deposits

\begin{tabular}{lllll}
\hline Sample population & Graphic mean grain size, $\Phi$ & Graphic standard deviation & Graphic skewness & Graphic kurtosis \\
\hline $\begin{array}{l}\text { Modern aeolian deposits } \\
\text { Aeolian sandstones }\end{array}$ & 2.54 & 0.51 & 0.01 & 0.95 \\
$\quad 382-386 \mathrm{~m}$ & 5.18 & & 0.46 & 1.91 \\
$866.6 \mathrm{~m}$ & 4.47 & 2.1 & 0.58 & 1.55 \\
$1138.8 \mathrm{~m}$ & 5 & 2.2 & 0.4 & 1.8 \\
Average & 4.88 & 2.1 & 0.48 & 1.75 \\
Lakeshore facies & & 2.13 & & 1.33 \\
$876 \mathrm{~m}$ & 6.12 & & 0.54 & 1.1 \\
$1140-1145 \mathrm{~m}$ & 5.74 & 2.75 & 0.48 & 1.59 \\
$1803.08 \mathrm{~m}$ & 3.72 & 3.14 & 0.39 & 0.47 \\
Average & 5.19 & 1.1 & 2.33 & \\
\hline
\end{tabular}
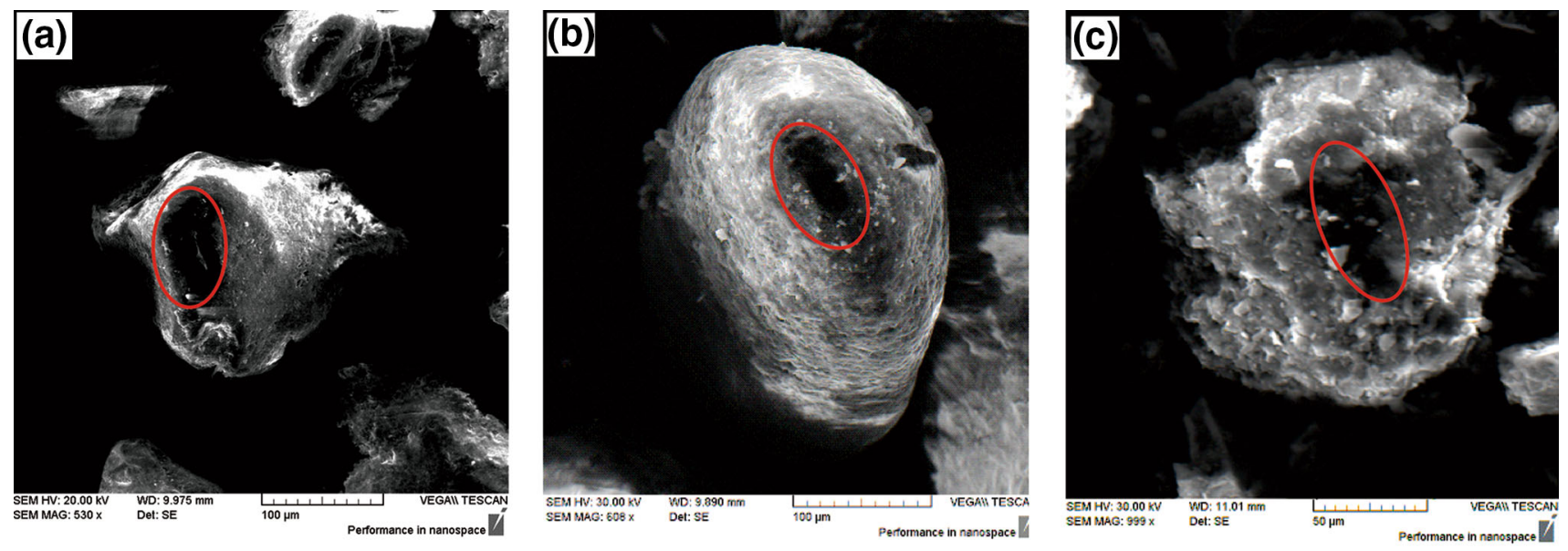

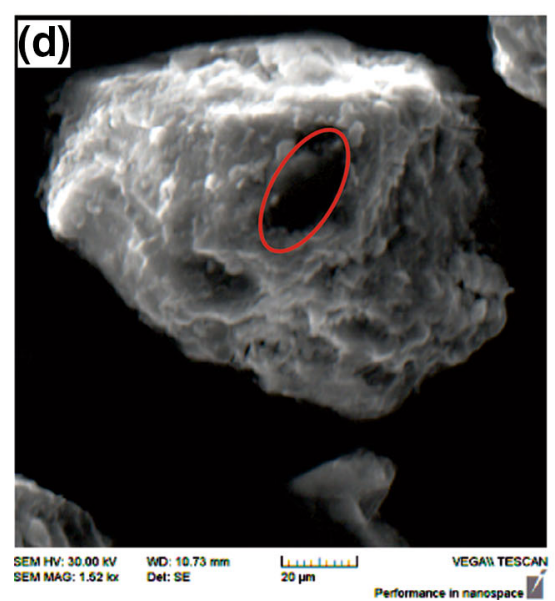

Fig. 5 Surface features of quartz grains from the Qigequan Formation and modern aeolian deposits. a Modern aeolian sands around Qinghai Lake. b Modern aeolian sands of Mingsha Mountain. c Aeolian core

(Fig. 5a, b), indicating wind transport over considerable distances ( $\mathrm{Ou}$ et al. 2008). Core material from $876 \mathrm{~m}$ (Fig. 5e) and $1803.08 \mathrm{~m}$ (Fig. 5f) does not show these
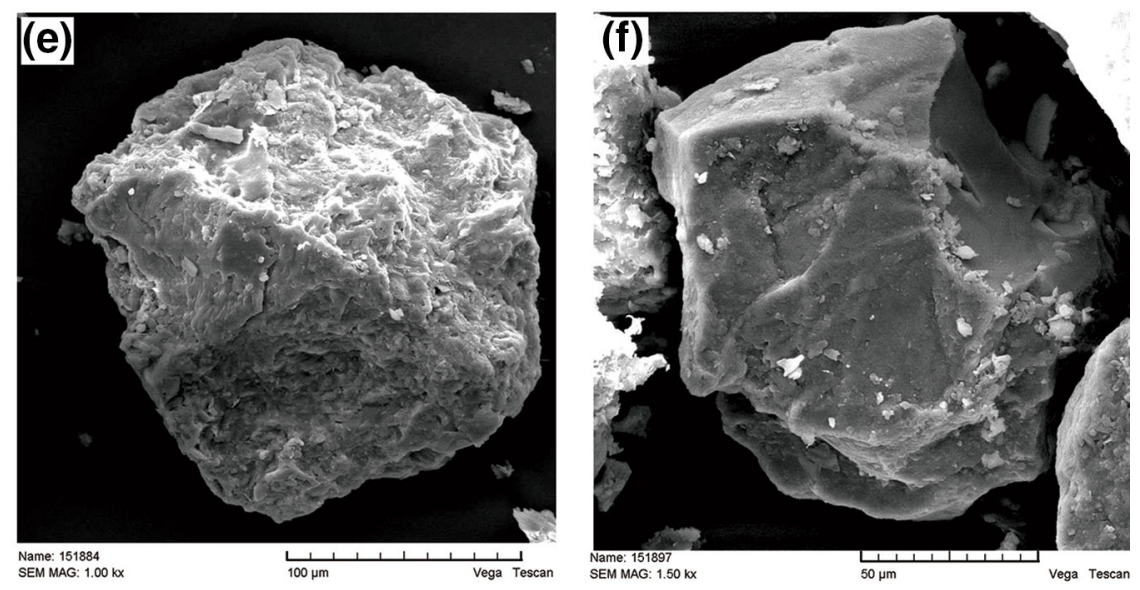

material at $866.6 \mathrm{~m}$. d Aeolian core material at $1138.8 \mathrm{~m}$. e Sand dam material at $876 \mathrm{~m}$. f Sand dam material at $1803.08 \mathrm{~m}$

patterns. This material may instead reflect a lakeshore sand dam. Sedimentary features indicate arid environments with significant diurnal temperature variation. 


\subsection{Geochemical characteristics and physical properties}

\subsubsection{Chemical compositions}

Previous studies suggest that wind transport alters clastic grain size distributions, chemical composition, and overall chemical content of aeolian deposits (Winspear and Pye 1996; Wu 2003). Chepil (1956) asserted that wind transport removes $\mathrm{Al}_{2} \mathrm{O}_{3}, \mathrm{CaO}, \mathrm{CO}_{2}$, and organic matter from sediment and causes relative enrichment in $\mathrm{SiO}_{2}$ and $\mathrm{Fe}_{2} \mathrm{O}$. Nesbitt and Young (1982) defined chemical index of alteration (CIA) parameters and established an analytical framework for sediments using $\mathrm{Al}_{2} \mathrm{O}_{3}, \mathrm{CaO}, \mathrm{K}_{2} \mathrm{O}$, and $\mathrm{Na}_{2} \mathrm{O}$ values. Honda and Shimizu (1998) found average CIA values of 54.6 in sediments from the Taklimakan desert. Kasper-Zubillaga et al. (2007) found that desert dune sediment composition is primarily influenced by sedimentation and source area rather than by chemical weathering. $\mathrm{Ou}$ et al. (2008) compared $\mathrm{SiO}_{2}, \mathrm{Al}_{2} \mathrm{O}_{3}$, and TOFE $\left(\mathrm{Fe}_{2} \mathrm{O}_{3}+\mathrm{FeO}\right)$ compositions of paleo-dune material, recent dune sands and fluvio-lacustrine sediments. These researchers found that chemical compositions of recent dune sands resembled those of paleo-dune sands. The ancient and recent dune material exhibited relative enrichment in $\mathrm{SiO}_{2}$ and relative depletion in $\mathrm{Al}_{2} \mathrm{O}_{3}$ and TOFE $\left(\mathrm{Fe}_{2} \mathrm{O}_{3}+\mathrm{FeO}\right)$ compared to the fluvio-lacustrine sediments. Hamdan et al. (2015) examined correlation between chemical compositions of aeolian sands in Upper Egypt and considered different source areas around Toshka Lake.

Table 3 lists major element compositions for 28 samples of the Qigequan Formation. Aeolian sandstones exhibited low $\mathrm{CaO}, \mathrm{K}_{2} \mathrm{O}, \mathrm{Al}_{2} \mathrm{O}_{3}, \mathrm{Fe}_{2} \mathrm{O}_{3}$, and $\mathrm{Mn}$, and high $\mathrm{SiO}_{2}$, $\mathrm{Na}_{2} \mathrm{O}$, and $\mathrm{MgO}$ compared to lakeshore sand dam sediment and lakeshore mudflat sediment. This variation probably reflects variation in chemical composition between different sedimentary microfacies associated with the respective sedimentary environments. During periods when humid climatic conditions prevailed, active elements (e.g. potassium and sodium) would dissolve and migrate due to acidic conditions in the aqueous medium. Stable elements (e.g. iron, aluminium, manganese) influenced by chemical weathering in the areas of high elevation would migrate and deposit in the low-lying areas, as opposed to the arid climatic conditions.

\subsubsection{Paleo-salinity estimate}

Estimates of paleo-salinity can be reconstructed from sedimentary chemical parameters to inform paleo-environmental interpretations. Paleo-salinity estimates for closed basinal systems can also capture changes in sedimentary environment. Paleo-salinity indicators tend to give low values for humid sedimentary environments and high values for arid environments (Patrickson et al. 2010). The lacustrine facies developed during deposition associated with the summer monsoon while the aeolian sandstones deposit formed during the winter monsoon (Ou et al. 2008). For this study, we used $\mathrm{Cl}$ concentrations to estimate paleosalinity and discern climatic effects.

The Qigequan Formation core material from Qijia 1 Well gave $\mathrm{Cl}$ concentrations ranging from $818 \mathrm{ppm}$ to $25.2 \%$, with mean values of $6234 \mathrm{ppm}$. Mudstones deposited and preserved within more sandy sediments gave $\mathrm{Cl}$ concentrations that could reflect salinity of ground water or surface depositional features (e.g. lakes). Concentrations of $\mathrm{Cl}$ from Qijia 1 Well core material indicate relatively high salinity during deposition of the Qigequan Formation. Associated lacustrine environments likely experienced saline to brackish water conditions. These characteristics indicate a relatively arid environment.

\subsubsection{Physical properties}

Porosity of aqueously deposited aeolian sandstones ranged from $29.9 \%$ to $38.7 \%$ and permeability ranged from $102 \times 10^{-3}$ to $581 \times 10^{-3}{\mu m^{2}}^{2}$ Core samples gave a mean porosity value of $33.0 \%$ and a mean permeability value of $274 \times 10^{-3} \mu^{2}$. Lakeshore sand dam material gave porosity values ranging from $21.6 \%$ to $30.5 \%$ with a mean value of $28.0 \%$ and permeability values ranging from

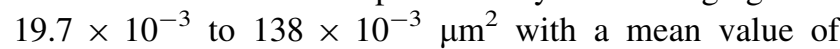
$95.1 \times 10^{-3} \mu \mathrm{m}^{2}$. These parameters support the interpretation that the Qijia 1 Well core material represents aeolian sandstones as it exhibits more void space than the lakeshore sand dam material.
Table 3 Chemical composition of sandstones in the Sanhu area, Qaidam Basin

\begin{tabular}{|c|c|c|c|c|c|c|c|c|c|c|}
\hline \multicolumn{10}{|c|}{ Chemical composition, $\%$} & \multirow[t]{2}{*}{ Microfacies } \\
\hline $\mathrm{CaO}$ & $\mathrm{K}_{2} \mathrm{O}$ & $\mathrm{Fe}_{2} \mathrm{O}_{3}$ & $\mathrm{P}$ & $\mathrm{Mn}$ & $\mathrm{Ti}$ & $\mathrm{Na}_{2} \mathrm{O}$ & $\mathrm{SiO}_{2}$ & $\mathrm{Al}_{2} \mathrm{O}_{3}$ & $\mathrm{MgO}$ & \\
\hline 3.74 & 2.55 & 5.59 & 0.06 & 0.05 & 0.38 & 3.60 & 67.67 & 13.10 & 3.26 & Aeolian sandstones \\
\hline 6.35 & 2.95 & 6.14 & 0.06 & 0.13 & 0.44 & 2.32 & 64.16 & 15.00 & 2.45 & Lakeshore sand dam \\
\hline 7.72 & 3.02 & 6.22 & 0.05 & 0.09 & 0.39 & 2.51 & 62.5 & 14.61 & 2.89 & Lakeshore mudflat \\
\hline
\end{tabular}




\section{Discussion}

Aqueously deposited aeolian sandstones of the Qigequan Formation are dominated by coarse to fine siltstones. Sandstones exhibit relatively higher $\mathrm{SiO}_{2}, \mathrm{Na}_{2} \mathrm{O}$, and $\mathrm{MgO}$ contents than the sand dam sediments in the lakeshore. Sandstones consist of well-sorted and rounded pure quartz. Microscopic (SEM) imaging of sandstones revealed dishshaped pits and crescent-shaped pits in the surface of clasts. These characteristics resemble aeolian deposits in the Salawusu River Valley (Ou et al. 2008) and central and south-western Nebraska (Winspear and Pye 1996) in the USA (Table 4).

Aeolian sand is mainly deposited on the lakeshore and in deserts. The sand dam on the lakeshore exhibits relatively low maturity, moderately poor sorting and roundness, and strong inheritance of provenance. In contrast, aeolian sand in the desert forms relatively thick layers and exhibits higher quartz content, high maturity and roundness and is well sorted. Based on the evidence listed, this paper infers that aeolian sands of the Qigequan Formation were deposited under aqueous conditions. Regional aeolian sediments are controlled by dynamic interactions between glacial, icemargin fluvial, aeolian and volcaniclastic processes under the influence of a distinctive climatic regime (Mountney and Russell 2004). Aeolian landforms serve as a long-term integrator of the effects of the strongest wind regimes in a region (Koster 1988). According to the research results, it is speculated that there are mainly two reasons for the formation of aqueously deposited aeolian sandstones in the Quaternary. (1) Pollen data indicates that the Qaidam Basin experienced relatively humid conditions during the Oligocene. The ancient Qaidam Lake gradually formed in the west of basin, which lay at a relatively low elevation at the time. Two episodes of Himalayan tectonic movement uplifted the Qaidam Basin and cut the basin off from ancient sedimentary source areas. Climatic evolution caused the lake to contract and become saline. In the Quaternary, widespread glacial intervals imply low-temperature climate conditions. The nearby Kunlun Mountains and Qilian Mountains host middle to early Pleistocene glacial features and the freshwater-less saline fossils typified by the ostracod Qinghaicypris crassa (2.34-2.52 Ma), indicating that the Qaidam Basin experienced low temperature conditions during the Quaternary.

Table 4 Summary of characteristics of the aeolian sandstones and fluvio-lacustrine sands of Qijia 1 Well in the Qaidam Basin, Salawusu Formation in the Salawusu River Valley and central and south-western Nebraska in USA

\begin{tabular}{|c|c|c|c|c|c|c|c|c|c|c|c|}
\hline \multirow{2}{*}{$\begin{array}{l}\text { Sample } \\
\text { population }\end{array}$} & \multirow[t]{2}{*}{ Colour } & \multirow{2}{*}{$\begin{array}{l}\text { Sorting and } \\
\text { roundness }\end{array}$} & \multicolumn{4}{|c|}{ Grain size } & \multirow{2}{*}{$\begin{array}{l}\text { Surface texture } \\
\text { characteristics of quartz } \\
\text { sands }\end{array}$} & \multicolumn{4}{|c|}{ Main chemical composition, $\%$} \\
\hline & & & $\begin{array}{l}M_{\mathrm{z}} \\
\Phi\end{array}$ & $\begin{array}{l}\sigma \\
\Phi\end{array}$ & $\mathrm{SK}_{1}$ & $\mathrm{~K}_{\mathrm{G}}$ & & $\mathrm{Fe}_{2} \mathrm{O}_{3}$ & $\mathrm{SiO}_{2}$ & $\mathrm{Al}_{2} \mathrm{O}_{3}$ & $\mathrm{Na}_{2} \mathrm{O}$ \\
\hline $\begin{array}{l}\text { Modern aeolian } \\
\text { deposits in } \\
\text { Mingsha } \\
\text { Mountain }\end{array}$ & Greyish yellow & Well & 2.54 & 0.51 & 0.01 & 0.95 & $\begin{array}{l}\text { Dish-shaped pits and } \\
\text { crescent-shaped pits }\end{array}$ & - & - & - & \\
\hline \multicolumn{12}{|c|}{ Qijia 1 Well in the Sanhu area, Qaidam Basin, China } \\
\hline $\begin{array}{l}\text { Aeolian } \\
\text { sandstones }\end{array}$ & Greyish yellow & Well & 4.88 & 2.13 & 0.48 & 1.75 & $\begin{array}{l}\text { Dish-shaped pits and } \\
\text { crescent-shaped pits }\end{array}$ & 5.59 & 67.67 & 13.1 & 3.6 \\
\hline $\begin{array}{l}\text { Lakeshore } \\
\text { facies }\end{array}$ & $\begin{array}{l}\text { Light greyish } \\
\text { yellow }\end{array}$ & $\begin{array}{l}\text { Moderately } \\
\text { poor }\end{array}$ & 5.19 & 2.33 & 0.47 & 1.34 & Without pit & 6.14 & 64.16 & 15 & 2.32 \\
\hline \multicolumn{12}{|c|}{ Salawusu Formation in the Salawusu River Valley, Egypt } \\
\hline $\begin{array}{c}\text { Paleo-aeolian } \\
\text { dune sands }\end{array}$ & $\begin{array}{l}\text { Greyish yellow } \\
\text { to light red } \\
\text { orange }\end{array}$ & Well & 2.98 & 0.71 & -0.05 & 1.42 & $\begin{array}{l}\text { Dish-shaped pits and } \\
\text { meander ridge, crescent- } \\
\text { shaped pits and } \\
\text { pockmarked pits }\end{array}$ & 2.01 & 79.77 & 7.83 & - \\
\hline $\begin{array}{l}\text { Fluvio- } \\
\text { lacustrine } \\
\text { facies }\end{array}$ & $\begin{array}{l}\text { Light greyish } \\
\text { yellow to } \\
\text { light greyish } \\
\text { green }\end{array}$ & $\begin{array}{l}\text { Moderately } \\
\text { poor }\end{array}$ & 2.72 & 0.56 & -0.2 & 1.1 & - & 8.65 & 72.67 & 2.81 & - \\
\hline \multicolumn{12}{|c|}{ Central and south-western Nebraska, USA } \\
\hline Aeolian sands & - & Well & 2.23 & 0.53 & -0.06 & 1.01 & - & 0.407 & 88.06 & 6.3 & 1.0 \\
\hline $\begin{array}{l}\text { Johnson fluvial } \\
\text { sands }\end{array}$ & - & $\begin{array}{l}\text { Moderately } \\
\text { poor }\end{array}$ & 2.17 & 0.8 & -0.02 & 0.93 & - & 1.093 & 88.61 & 7.78 & 1.09 \\
\hline
\end{tabular}


The uplift of the Himalayas and the Qinghai-Tibet Plateau also blocked humid air travelling from the Indian Ocean to the basin (Harris 2006; Boos and Kuang 2010; Molnar et al. 2010). Abundant nutrients contributed to planktonic blooms and associated organic carbon accumulation (Zachos and Kump 2005). Draw down of carbon dioxide contributed to climate change in the Qaidam Basin, which provides the direct conditions for the aeolian sandstones. (2) In the early Oligocene, an ancient lake gradually formed in the western Qaidam Basin due to the warm climate. However, neo-tectonic movements led to the uplift and subsidence of the basin, and the ancient Qaidam Lake was segmented into two parts with one depocentre migrating from west to east. During the Quaternary, lacustrine sediments accumulated mostly in the Sanhu area. An extensive, semi-deep lacustrine depocentre formed in the Taijinar and Dabsan Lake regions. The present-day lake margin has also inherited layout and other sedimentary features from the early Pleistocene lake, including a northerly lakeshore primarily dominated by mud deposition and marshlands, and a southerly margin dominated by sand deposition. Uplifted sandy lacustrine deposits exposed over a large area provided ample sediment source for the observed aeolian deposits.

Discovery of aqueously deposited aeolian sandstones further strengthens the evidence that Qaidam Basin experienced arid-cold paleoclimatic conditions and strong wind during the Pleistocene.

\section{Conclusions}

Aqueously deposited aeolian sandstones of the Qigequan Formation are dominated by coarse to fine siltstones. Sandstones exhibit relatively higher $\mathrm{SiO}_{2}, \mathrm{Na}_{2} \mathrm{O}$, and $\mathrm{MgO}$ contents than the sand dam sediments in the lakeshore. Sandstones consist of well-sorted and rounded pure quartz clasts with single mode grain size distribution and few suspension materials. Microscopic (SEM) imaging of sandstones revealed dish-shaped pits and crescent-shaped pits in the surface of grains.

The Salt Lake of Sanhu likely represents the source area for the aeolian sandstones. Glacial deposits and uplift of the Himalayas and Qinghai-Tibet Plateau caused arid-cold paleoclimatic conditions and strong wind in the Qaidam Basin. Sediments partially lithified in the Pleistocene were eroded by stronger winds that developed during this time. Sandstones were transported to the Salt Lake by wind and accumulated in the lake's depocentre.

Acknowledgements This research received funding support from the Qinghai Oilfield Company of the China National Petroleum Corporation.
Open Access This article is distributed under the terms of the Creative Commons Attribution 4.0 International License (http://crea tivecommons.org/licenses/by/4.0/), which permits unrestricted use, distribution, and reproduction in any medium, provided you give appropriate credit to the original author(s) and the source, provide a link to the Creative Commons license, and indicate if changes were made.

\section{References}

Abdullah MA, Eswaran P. Quartz surface morphology of tertiary rocks from North East Sarawak, Malaysia: implications for paleo-depositional environment and reservoir rock quality predictions. Pet Explor Dev. 2014;41(6):761-70. https://doi.org/10. 1016/S1876-3804(14)60090-2.

Bertran P, Bateman MD, Hernandez M, et al. Inland aeolian deposits of south-west France: facies, stratigraphy and chronology. J Quat Sci. 2011;26(4):374-88. https://doi.org/10.1002/jqs.1461.

Bertran P, Liard M, Sitzia L, et al. A map of Pleistocene aeolian deposits in Western Europe, with special emphasis on France. J Quat Sci. 2016;31(8):844-56. https://doi.org/10.1002/jqs.2909.

Boos WR, Kuang Z. Dominant control of the South Asian monsoon by orographic insulation versus plateau heating. Nature. 2010;463(7278):218-22. https://doi.org/10.1038/nature08707.

Chepil WS. Influence of moisture on erodibility of soil by wind. Soil Sci Soc Am. 1956;20(2):288-92. https://doi.org/10.2136/ sssaj1956.03615995002000020033x.

Cowan EA, Hillenbrand CD, Hassler LE, et al. Coarse grained terrigenous sediment deposition on continental rise drifts: a record of Plio-Pleistocene glaciation on the Antarctic Peninsula. Palaeogeogr Palaeoclimatol Palaeoecol. 2008;265(3-4):275-91. https://doi.org/10.1016/j.palaeo.2008.03.010.

Deane SM. Quartz grain microtextures and sediment provenance: Using scanning electron microscopy to characterize tropical highland sediments from Costa Rica and the Dominican Republic. Knoxville: University of Tennessee, Knoxville; 2010. p. 56-72.

Fang XM, Zhang WL, Meng QQ, et al. High-resolution magnetostratigraphy of the Neogene Huaitoutala section in the eastern Qaidam Basin on the NE Tibetan Plateau, Qinghai Province, China and its implication on tectonic uplift of the NE Tibetan Plateau. Earth Planet Sci Lett. 2007;258(1):293-306. https://doi. org/10.1016/j.epsl.2007.03.042.

Goudie AS. The character and possible origins of the aeolian sediments of the Wahiba sand sea, Oman. Geogr J. 1987;153(2):231-56. https://doi.org/10.2307/634875.

Guo SB. Sequence stratigraphy of the quaternary Qigequan Group, Qaidam Basin, Western China. Int Geol Rev. 2008;50(8):755-62. https://doi.org/10.2747/0020-6814.50.8.755.

Guo SB, Chen CL. Sequence stratigraphy of Quaternary Qigequan Group of the Sanhu depression and prediction for prospective targets for hydrocarbons. Earth Sci Front. 2008;15(2):43-50. https://doi.org/10.3321/j.issn:1005-2321.2008.02.006 Chinese).

Guo ZQ, Liu WH, Feng G. Distribution regularities and favorable exploration areas of lithologic gas reservoir in Sanhu area, Qaidam Basin. Nat Gas Geosci. 2011;22(4):635-41 (in Chinese).

Hamdan MA, Refaat AA, Anwar EA, et al. Source of the aeolian dune sand of Toshka area, southeastern Western Desert, Egypt. Aeolian Res. 2015;17:275-89. https://doi.org/10.1016/j.aeolia. 2014.08.005.

Harris N. The elevation history of the Tibetan Plateau and its implications for the Asian monsoon. Palaeogeogr Palaeoclimatol 
Palaeoecol. 2006;241(1):4-15. https://doi.org/10.1016/j.tecto. 2014.01.036.

Honda M, Shimizu H. Geochemical, mineralogical and sedimentological studies on the Taklimakan Desert sands. Sedimentology. 1998;45(6):1125-43. https://doi.org/10.1046/j.1365-3091.1998. 00202.x.

Hu G, Wang NA, Luo JY, et al. The grain size characteristics of aeolian sand and its environmental significance. Acta Sedimentol Sin. 2001;19(4):642-7. https://doi.org/10.3969/j.issn.1000-0550. 2001.04 .027 (in Chinese).

Kasper-Zubillaga JJ, Zolezzi-Ruiz H, Carranza-Edwards A, et al. Sedimentological, modal analysis and geochemical studies of desert and coastal dunes, Altar Desert, NW Mexico. Earth Surf Proc Land. 2007;32(4):508-98. https://doi.org/10.1002/esp. 1402.

Koster EA. Ancient and modern cold-climate aeolian sand deposition: a review. J Quat Sci. 1988;3(1):69-83. https://doi.org/10.1002/ jqs.3390030109.

Lu HY, Vandenberghe J, An ZS. Aeolian origin and palaeoclimatic implications of the 'red clay' (north China) as evidenced by grainsize distribution. J Quat Sci. 2001;16(1):89-97. https://doi.org/10. 1002/1099-1417(200101)16:1<89:AID-JQS578>3.0.CO;2-8.

Mahaney WC, Stewart A, Kalm V. Quantification of SEM microtextures useful in sedimentary environmental discrimination. Boreas. 2001;30(2):165-71. https://doi.org/10.1111/j.15023885.2001.tb01220.x.

Mongelli G, Critelli S, Perri F, et al. Sedimentary recycling, provenance and paleoweathering from chemistry and mineralogy of Mesozoic continental redbed mudrocks, Peloritani mountains, southern Italy. Geochem J. 2006;40(2):197-209. https://doi.org/ 10.2343/geochemj.40.197.

Molnar P, Boos WR, Battisti DS. Orographic controls on climate and paleoclimate of Asia: thermal and mechanical roles for the Tibetan Plateau. Annu Rev Earth Planet Sci. 2010;38(1):77-102. https://doi.org/10.1146/annurev-earth-040809-152456.

Mountney NP, Russell AJ. Sedimentology of cold-climate aeolian sandsheet deposits in the Askja region of northeast Iceland. Sed Geol. 2004;166(3-4):223-44. https://doi.org/10.1016/j.sedgeo. 2003.12.007.
Mountney NP, Russell AJ. Aeolian dune-field development in a water table-controlled system: skeidararsandur, Southern Iceland. Sedimentology. 2009;56(7):2107-31. https://doi.org/10.1111/j. 1365-3091.2009.01072.x.

Nesbitt HW, Young GM. Early Proterozoic climates and plate motions inferred from major element chemistry of lutites. Nature. 1982;299(5885):715-7. https://doi.org/10.1038/ $299715 \mathrm{a} 0$.

Ou X, Li BS, Jin HL, et al. Sedimentary characteristics of paleoaeolian dune sands of Salawusu Formation in the Salawusu River Valley. J Geog Sci. 2008;18(2):211-24. https://doi.org/10.1007/ s11442-008-0211-5.

Patrickson SJ, Sack D, Brunelle AR, et al. Late Pleistocene to early Holocene lake level and paleoclimate insight from Stansbury island, Bonneville Basin, Utah. Quat Res. 2010;73(2):237-46. https://doi.org/10.1016/j.yqres.2009.12.006.

Refaat AA, Hamdan MA. Mineralogy and grain morphology of the aeolian dune sand of Toshka area, southeastern Western Desert. Aeolian Res. 2015;17:243-54. https://doi.org/10.1016/j.yqres. 2009.12.006.

Winspear NR, Pye K. Textural, geochemical and mineralogical evidence for the sources of aeolian sand in central and southwestern Nebraska, U.S.A. Sed Geol. 1996;101(1-2):85-98. https://doi.org/10.1016/0037-0738(95)00049-6.

$\mathrm{Wu}$ Z. Aeolian geomorphology and rehabilitation engineering. Beijing: Science Press; 2003. p. 15-80 (in Chinese).

Xie QB, Guan CR. Sedimentary facies type and reservoir evaluation for the northern Qaidam Basin. Pet Explor Dev. 2000;27(2):40-4. https://doi.org/10.3321/j.issn:1000-0747.2000. 02.011 (in Chinese).

Zachos JC, Kump LR. Carbon cycle feedbacks and the initiation of Antarctic glaciation in the earliest Oligocene. Global Planet Change. 2005;47(1):51-66. https://doi.org/10.1016/j.gloplacha. 2005.01 .001$.

Zhang ZC, Dong ZB, Zhao AG. The characteristics of aeolian sediment flux profiles in the south-eastern Tengger Desert. Sedimentology. 2011;58(7):1884-94. https://doi.org/10.1111/j. 1365-3091.2011.01243.x. 